\title{
12 The impact of the pandemic on the Italian regional system
}

\author{
Centralizing or decentralizing effects?
}

\author{
Francesco Palermo
}

\subsection{Introduction}

Italy has been severely affected by the COVID-19 pandemic, with a proportionately high number of infections and even bigger mortality rate, due to the large amount of elderly people (22.7 percent of the residents being over 65 years, the highest percentage in Europe). As of 31 December 2020, of a population of about 60 million, slightly more than 2 million people had been infected, with about 75,000 casualties. The impact was extremely uneven among the territories in the 'first wave' (February to June), with the overwhelming majority of the cases being concentrated in just a handful of regions in the north of the country. These areas are the more industrialized parts of the country and hence more exposed to trade with foreign nations. In the 'second wave,' that started in October, the distribution of the infection was far more uniform and affected the whole territory in a similar fashion.

Italy's territorial design comprises 20 Regions, 5 of which have special status and powers (Arban, Martinico and Palermo 2021). Regions are responsible for a wide range of areas including, in particular, organizing and delivering health care (Cicchetti and Gasbarrini 2016). The country's territorial setup has been under discussion since its inception. Its hybrid configuration, in between a full-fledged federal system and a unitary country, has evolved over the last seven decades with a steady expansion of regional powers. When the pandemic reached the country, in early 2020, Italy was facing several transformations in its regional system, which on one hand were put on hold due to the emergency, but on the other raised new concerns and proposals for (counter-) reforms.

The chapter illustrates the legal framework put in place at the national (state) and the subnational (regional) level to face the health emergency and the policy challenges raised or amplified by the pandemic affecting the territorial organization. After a first phase of extreme centralization of powers, the regions (and to some extent the municipalities) gradually resumed their functions. The asymmetric impact of the virus

Table 12.1 Key Statistics on COVID-19 in Italy as of 10 January 2021

\begin{tabular}{lllll}
\hline $\begin{array}{l}\text { Cumulative } \\
\text { Cases }\end{array}$ & $\begin{array}{l}\text { Cumulative Cases per } \\
100,000 \text { Population }\end{array}$ & $\begin{array}{l}\text { Cumulative } \\
\text { Deaths }\end{array}$ & $\begin{array}{l}\text { Cumulative Deaths per } \\
100,000 \text { Population }\end{array}$ & $\begin{array}{l}\text { Case Fatality } \\
\text { Percentage }\end{array}$ \\
\hline $2,257,866$ & $3,734.4$ & 78,394 & 129.7 & 3.5 \\
\hline
\end{tabular}

Source: World Health Organization Weekly epidemiological update - 12 January 2021. Geneva: WHO, 2021. Available from https://www.who.int/publications/m/item/weekly-epidemiological-update

DOI: $10.4324 / 9781003251217-12$ 
and the equally asymmetric response by the territories revealed both the potential of such an asymmetric territorial governance and the weaknesses of an incomplete, quasi-federal system, especially as far as unclear division of powers and insufficient intergovernmental relations (IGR) are concerned (Table 12.1).

\subsection{Facts and legal framework}

Italy has been the first European country to be hit by the coronavirus pandemic and to declare the state of emergency, imposing a strict lockdown. After the first, dramatic moments in March and April, it managed to keep the contagion under control until the spread of a new wave of epidemic in the fall and the winter. On 31 January 2020, far ahead of any other European country, the state of emergency was declared by the national government for a period of six months, subsequently prolonged for further periods of six months each.

The constitution does not regulate the state of emergency in detail. It provides however that, "in case of necessity and urgency," the government may adopt "law decrees," that is, "temporary measures having force of law" which are valid for no longer than two months unless they are in the meantime adopted as formal laws by Parliament (art. 77). The state of emergency was declared based on a statutory, not a constitutional provision, the 2018 Civil Protection Act, which empowers the government to adopt "any necessary measure" within the limits of the "general principles of the legal system." In the course of 2020, 26 such legislative measures have been enacted, 22 regulations (decrees of the Prime Minister), and several administrative provisions by individual ministries, by the national civil protection and by the commissioner against the COVID-19 emergency (Italian Government, 2021).

What is striking about the legal response to the pandemic is that, in the initial stage, when the emergency was acute, the rules that had been adopted were nearly all national despite the fact that the impact of the virus has been extremely uneven among the regions. Conversely, when the spread of the virus became more uniform as of the fall, the response was more attentive to regional autonomy and to the need to tailor the measures to the socio-economic and health-care conditions of the different regions.

\subsubsection{The initial strong centralization}

Initially, the north was hit much more than the south: until September 2020, Lombardy, which accounts for one sixth of the national population (10 million), had about two fifths of the total number of infections $(110,000)$ and almost half of all casualties (over 17,000). Conversely, some southern regions have been very marginally affected: Calabria (2 million people) had 2,000 cases and 98 deaths and Basilicata $(560,000$ inhabitants) registered just 920 cases and 28 deaths, as of early October. Despite such differences as well as the fact that health care is a regional power, the early call for the state of emergency massively concentrated the decision-making in the national government. The detailed national provisions applied with no exception on the whole national territory and the margins for the regions were limited to the small niches deliberately left open by the national rules, allowing regions to adopt more restrictive provisions than the national ones, but preventing them to be less strict in any 
area. The regions were consulted prior to the adoption of national regulations, but consultation was rather a formal exercise, as they cannot oppose measures taken for the overarching sake of protecting public health and national security. As a matter of fact, between March and May 2020, the Standing Conference between the State and the Regions, the prime body for cooperation between the levels of government, which expresses (mostly non-binding) opinions on national legislation when regional interests are affected, met (online) only twice a month, that is, less than in normal times (Cortese 2020).

The regional governors (who are directly elected by the people in all but two Regions or autonomous Provinces and thus bear a significant political weight) were allowed to adopt their own regulations, although only to the extent that was permitted by the national legislation or to introduce stricter rules than the national ones. For example, Regions could determine the distance that people could walk from home, whether walking a dog was allowed, and little more. The national government was adamant in opposing regional attempts to take own initiatives: when in February, the governor of Marche, a region in central Italy that by then had not a single case of infection, declared his intention to close schools, he was called by the Prime Minister during the very press conference. The regional act was immediately challenged before the administrative court and suspended. In general, however, the Regions did not show special interest in being proactive at that stage, as this would have meant conflict with Rome and a degree of responsibility that normally Regions are not ready to take.

Centralization was also conditioned by the heavy hand of the central government on the measures to tackle the devastating economic impact of the pandemic. The 2020 national budget has devoted 179 billion euros ( 75.3 being additional debt) to tackle the crisis. The lion's share went to subsidies for companies (69.3 billion), followed by support for families (53.3 billion) and for jobs (34.5 billion). Other significant funds were provided for public health system ( 8.3 billion), regions and municipalities (6.4 billion), public services (5.4 billion), and social subsidies (1.5 billion; Italian Government 2020).

In sum, during the first months, the response to the emergency was characterized by strong centralization of powers both horizontally (from parliament to the government) and vertically (from the Regions to the center). The national regulations formally stressed the need for a better coordination among the levels of government, which in the end meant steering from the top down (Betzu and Ciarlo 2020). Especially in the first phase of the emergency, in March and April, such centralization was generally supported in the political and the public discourse. The main newspapers sharply criticized the attempts by some Regions to introduce small changes, even when this was allowed by national legislation. Conversely, more rigid regional measures were generally applauded, such as in the case of southern Regions further limiting the movement of people returning home from the north.

\subsubsection{Decentralization reappears}

Things started to change at the beginning of May, when the number of new infections dropped, the pressure on the health system was less acute, and the national government eased the lockdown. In that moment, the role of the Regions grew in proportion 
to the lifting of the national regulations, and subnational actors came back in the picture. Paradoxically, however, more normality did not bring clearer rules, but rather the opposite. This is because the business of government did not fully go back to the constitutional routine, as national emergency rules, while more limited, remained in place. This produced a growing number of conflicts since the Regions started to assert their own constitutional powers and acknowledged that the public health situation was very different across and within the Regions. The Regions sometimes deliberately challenged the national government for political reasons, with the Regions led by center-right parties (two thirds of the total) stronger opposing the center-left majority in Rome, after a short period of political ceasefire. As a matter of fact, while some regional provisions were suspended, others with the same content were not, further increasing legal uncertainty.

A few Regions started to adopt own laws, especially on economic support for companies and for sorting out bureaucratic issues (payments and the like). However, only the autonomous province of Bolzano/Bozen (South Tyrol), the northernmost territory predominantly inhabited by a German-speaking minority and ruled by the party representing such minority, made use of its broader autonomy and passed a law on 8 May, providing the complete restart of activities ahead of the rest of the country. The national government initially challenged part of the law before the constitutional court, but soon withdrew the lawsuit. South Tyrol was also the only Region that engaged in cross-border activities during the closure of borders: thanks to special bonds and institutionalized cooperation with Austria and particularly with the Land Tyrol, it succeeded in negotiating some exceptions to the prohibition of trans-frontier movement and a few people from South Tyrol could be hospitalized in Austria at the peak of the pandemic. It also served as a bridge when it negotiated with Austria the supply of face masks imported from China and distributed a share of them to the rest of Italy, when there was a nation-wide shortage.

While regional legislation remained limited, a flood of regional (over 1,000) and (countless) municipal provisions was passed, raising criticism for adding confusion rather than clarity (Scaccia and D'Orazi 2020). Many regional measures addressed economic activities (re-opening of pubs, restaurants, hotels, and other businesses), sport events (authorization and admission of the public), leisure (in some Regions discos were reopened during the summer, in others they were not), transport (number of persons allowed in regional trains and busses), or public health measures (some Regions introduced obligatory tests for persons travelling from abroad and even from other Regions). The conflict potential was aggravated by a certain confusion in the distribution of emergency powers: when it comes to the adoption of "urgent measures to counter sanitary and public hygiene emergencies," these can be taken by the mayor (art. 50.5 d.lgs. 267/2000), by the regional governor (art. 32.3 law 833/1978), and by the national government under the national state of emergency (d.lgs. 1/2018). This overlap of powers, coupled with the proliferation of "insufficiently coordinated" (Baldini 2020, p. 985) national and regional measures, made it very difficult to clearly understand who was responsible for such measures. A rather dramatic case occurred in Sicily, as the regional governor ordered to evacuate the hotspots for migrants, which were overcrowded due to an influx of migration from Africa in the summer and could not meet the sanitary restrictions. The national government opposed that migration is within exclusive national jurisdiction and suspended the provision, the Region challenged the suspension in the administrative court and eventually lost the case. 


\subsubsection{Second wave and new conflicts}

The picture became more complex when, in October, the second wave of the pandemic hit the country, with even more severe effects in sanitary terms. Unlike in the first phase, the outbreak affected all Regions to a relatively similar degree, exacerbating the problems of some regional health care system (especially in the South) with lower reaction capacity.

Learning from the experience of the first wave, the national government' approach was more open to regional differentiation. The new round of measures was focused especially on the economic consequences of the pandemic, providing for massive financial interventions to support companies, small business, and families, also in view of the funds that were agreed upon at EU level (an impressive total of $€ 1.8$ trillion in the whole Union). When new restrictions were imposed, the different conditions of each territory were considered, and a broader margin of regional intervention was allowed, while keeping the general rule according to which national provisions could be derogated only to adopt stricter but not softer measures.

Within the framework laid down in national legislation, Regions could decide on many significant aspects such as closing of schools, local transport, and freedom of movement within the regional territory. This created a more differentiated normative picture, with at times a patchwork of confusing regulations with a number of paradoxical outcomes. For example, in several Regions (especially in the South), schools remained closed for much longer than in others, due to fears that the weak regional health care system could not sustain a growing number of infections as well as to the inability to reorganize public transportation in a way that could accommodate all students while keeping the social distance. An extreme and somewhat funny example of normative overlap and confusion was the unilateral decision of a regional health authority in September to ban a professional football team of the first division from travelling to another region to play a match because a few players were tested positive, disregarding the special protocol negotiated by the national government and the football league which regulates such cases for the sake of regularly playing the championship.

Unlike in the previous phase, the new national measures were taken in accordance with the Regions. The main body in charge of intergovernmental relations - the Standing Conference between the State and the Regions - was summoned much more frequently and was involved in the adoption of all decisions. In spite of that, neither the degree of political confrontation nor the legal uncertainty decreased. A telling example is the law adopted by the autonomous Region of Aosta Valley in November, indeed very similar to the one of South Tyrol from May. The national government challenged the law in the constitutional court, which first suspended its effects and later (February 2021) struck it down in its entirety simply (and simplistically) arguing that Regions have no power to adopt such laws as the jurisdiction on international prophylaxis belongs exclusively to the State (judgment no. 37/2021).

Similarly, also policy responses at regional level have been subject to volatile political dynamics. No clear pattern as to effective or ineffective strategies in coordination and cooperation can be traced along party politics. Rather, it seems that other factors determine to what extent regional (and local) governing practices are 
more or less dependent on and affected by the national level. These include the very different fiscal capacities among the Regions, deep differences in health care models (Toth 2014), capacities in regionalized administration, and political personality of regional governors. The regional elections in seven Regions in September 2020 (Veneto, Liguria, Tuscany, Marche, Campania, Puglia, and Aosta Valley) confirmed the mandate of the governors who performed well during the first wave and/or profiled themselves as champions of a clear approach to fight the pandemic, be it advocating stricter rules such as school closure and curfews or supporting the economic sector by calling for more openings of bars, restaurants, and other economic activities.

\subsection{Pandemic and reforms: COVID-19 as an accelerator?}

When the COVID-19 pandemic hit Italy, the country was about to celebrate the 50th anniversary of the establishment of Regions in the whole territory. Prior to 1970, only five, so-called special Regions existed in its periphery, making Italy the state that has the longest-lasting regional (as opposed to federal) system in place worldwide (since 1948). After several transformations which over more than seven decades enhanced the powers of Regions, time was ripe for reconsidering the territorial structure of the country. Furthermore, three sizeable and economically as well as politically strong Regions in the north, Lombardy, Veneto, and Emilia-Romagna were about to conclude agreements with the national government on the transfer of additional legislative powers (and connected funds) in a long and significant list of areas, from environmental protection to education, from airports to labor security and protection, from foreign trade to disaster management and others. This procedure is provided for by the constitution (art. 116.3) since 2001 but has not been activated thus far. The process was stalled due to the pandemic, and ironically, these regions have been the more affected by the virus, which raised the question as to whether more regional autonomy is desirable or to be opposed (Malo 2020). Finally, a constitutional reform was voted in a national referendum on September 20, which reduced the size of both chambers of the national parliament, this way further limiting the already feeble link between the Senate and the regions and making it politically more difficult to table a reform of the Senate transforming it into a regional representation (Vuolo 2020), a proposal that has been on the agenda for decades but could never be implemented so far.

The pandemic will strongly impact on these ongoing reform processes. Institutional consequences cannot be expected in the short run, as the sanitary and the subsequent economic emergencies are prevailing, and there is no consensus on the territorial design of the country. Proposals have been put forward to include provisions on the state of emergency in the constitution, following the Spanish model (Ceccanti 2020), but the chances for such a reform seem rather limited in the short term. For sure, however, the emergency has revealed the main weaknesses of the Italian regional system: the unclear division of powers between the center and the Regions; the weak intergovernmental relations; and the high degree of asymmetry in powers, administrative capacity, and political strength among the regions (Clementi 2020, who adds the relations between government and parliament at national level). 


\section{Francesco Palermo}

As to the division of powers, a constitutional reform adopted in 2001 has increased the role of the Regions but has created a number of overlaps and conflict potential (Arban, Martinico and Palermo 2021) and above all has by no means enhanced the "federal spirit" (Burgess 2012), making Italy "a federal country without federalism" (Palermo 2012). Rather, in the political and academic debate, sentiments against regional autonomy are overall on the rise. Like after the economic crisis around 2010 (Valdesalici 2014), the pandemic has confirmed that the division of powers is not sound enough to resist a moment of crisis, and in fact, it amplified the ongoing debate between advocates for more centralization and advocates for more autonomy, with the former being prevalent in the political and also in the academic debate. In particular, the existence of 21 regional healthcare systems, very different as to their effectiveness in service delivery, is sharply criticized and might be subject to pressures for recentralization.

With regard to IGRs, the absence of a territorial chamber and the structural weakness of the existing bodies for intergovernmental cooperation, and notably of the Standing Conference, reduced regional involvement to a mere formality when the center appropriated all powers at the peak of the emergency. In such moments, when stronger coordination is required, the role of mechanisms that effectively represent the voice of the subnational entities becomes crucial. When these mechanisms are ineffective, as in the case of Italy, joint decisions simply become top-down impositions, and the involvement of Regions becomes mere lip service. This happened also when territorial interests were taken into more account, as it was ultimately a national decision to do so. Inefficiency of multilateral IGR mechanisms encourages the more powerful regions to engage in bilateral negotiations thus accentuating the asymmetry inherent in the design of the territorial setup and arousing jealousy among the Regions.

The strong asymmetries, de jure and de facto (Watts 2008) already existing among the Italian Regions, have become ever more visible and acute with the pandemic. The regional performance in tackling the emergency, especially in the area of health care, has been mixed. Some Regions have done extraordinarily well, despite the severe cuts over the past decade due to the debt-cutting policies, while others made serious mistakes, such as placing COVID-patients in elderly homes (Giarelli and Vicarelli 2020). The differences in performance were reflected in the political sphere, with some regional governors increasing their popular support and others losing it.

In sum, COVID-19 put the existing tensions between calls for further decentralization and for re-centralization under the spotlight and amplified them. At the same time, the ongoing reform processes will be significantly impacted, and their trajectory will not be the same as it would have been without the pandemic. The main pressure is no doubt for a certain degree of re-centralization of public health, which is almost entirely in the hands of the regions and makes up over 80 percent of the regional budgets. Even though most Regions reacted well, the dominant discourse underlines the existing big differences in terms of services, resources, and performance, and it is not unlikely that the opportunity will be seized to introduce a stronger control by the national government (Ciardo 2020). For some reason, the dominant attitude in both politics and academia on one hand fears that regional differentiation might impair 
the equal protection of social rights, but on the other hand, it trusts that national legislation is per se better and safer, although comparative practice seems to prove the opposite (Palermo 2020).

Some reforms in the Italian regional system are indeed necessary, and the pandemic made this ever more evident. As to the content of the reforms, however, opinions were all but unanimous before the pandemic and became even more divergent after it. The further diversion of opinions will probably slow down rather than speed up the necessary reforms and increase the conflicts between the center and the territories.

\section{Bibliography}

Arban, E., Martinico, G. and Palermo, F. (eds.), 2021. Federalism and Constitutional Law: The Italian Contribution to Comparative Regionalism. London: Routledge.

Baldini, V., 2020. Riflessioni sparse sul caso (o sul caos) normativo al tempo dell'emergenza costituzionale. Dirittifondamentali.it, 1, 979-985.

Betzu, M. and Ciarlo, P., 2020. Epidemia e differenziazione territoriale. BioLaw Journal, Special Issue (1), 201-208.

Burgess, M., 2012. In Search of the Federal Spirit. Oxford: Oxford University Press.

Ceccanti, S., 2020. Verso una regolamentazione degli stati di emergenza per il parlamento: proposte a regime e possibili anticipazioni immediate. BioLaw Journal, Special Issue (1), 71-78.

Ciardo, C., 2020, Il Servizio Sanitario Nazionale alla prova dell'emergenza COVID-19: il rischio di una sanità diseguale. BioLaw Journal, Special Issue (1), 227-238.

Cicchetti, A. and Gasbarrini, A., 2016. The Healthcare Service in Italy: Regional Variability. European Review for Medical and Pharmacological Sciences 20 (1 Suppl.), 1-3.

Clementi, F., 2020. Il lascito della gestione normativa dell'emergenza: tre riforme ormai ineludibili. Osservatorio costituzionale, 3, 33-47.

Cortese, F., 2020. Stato e Regioni alla prova del coronavirus. Le Regioni, XLVIII (1), 3-10.

Giarelli, G. and Vicarelli, G., 2020. Politiche e sistemi sanitari al tempo della pandemia da COVID-19: una lettura sociologica. Sociologia italiana 16, 69-86.

Italian Government, 2021. Coronavirus. La normativa vigente (Information on the Provisions Adopted to Counter the Virus and Its Effects). Available from: http://www.governo.it/it/ coronavirus-normativa

Italian Government, 2020. Documento di Economia e Finanza 2020, Sect. III, Programma Nazionale di Riforma. Available from: http://www.dt.mef.gov.it/modules/documenti_it/ analisi_progammazione/documenti_programmatici/def_2020/DEF_2020_Programma_ Nazionale_di_Riforma.pdf

Malo, M., 2020. Le Regioni e la pandemia. Variazioni sul tema. Le Regioni, XLVIII (1), 231-234.

Palermo, F., 2012. "Italy: A Federal Country without Federalism?” In: Burgess, M. and Tarr, G.A., eds. Constitutional Dynamics in Federal Systems. Sub-National Perspectives. Montreal \& Kingston: McGill-Queen's University Press, 237-254.

Palermo, F., 2020. Is There a Space for Federalism in Times of Emergency? Verfassungsblog (5) 13. Available from: https://doi.org/10.17176/20200513-133602-0.

Scaccia, G. and D'Orazi, C., 2020. La concorrenza fra Stato e autonomie territoriali nella gestione della crisi sanitaria tra unitarietà e differenziazione. Forum Quaderni costituzionali, (3), 108-120.

Toth, F., 2014. How Health Care Regionalisation in Italy Is Widening the North-South Gap. Health Economics, Policy and Law, 9 (3), 231-249. 


\section{Francesco Palermo}

Valdesalici, A., 2014. Features and Trajectories of Fiscal Federalism in Italy. In: Lütgenau, S.A., ed. Fiscal Federalism and Fiscal Decentralization in Europe. Comparative Case Studies on Spain, Austria, the United Kingdom and Italy. Innsbruck: StudienVerlag, 73-101.

Vuolo, A., 2020. L'insostenibile imperfezione del bicameralismo perfetto. Diritto Pubblico Europeo - Rassegna Online. Available from: https://doi.org/10.6092/2421-0528/6718.

Watts, R.L., 2008. Comparing Federal Systems. Montreal \& Kingston: McGill-Queen's University Press. 